NASA Technical Memorandum 100964

AIAA-88-3154

\title{
Aeroelastic Response of Metallic and Composite Propfan Models in Yawed Flow
}

Krishna Rao V. Kaza

National Aeronautics and Space Administration

Lewis Research Center

Cleveland, Ohio

Marc H. Williams

Purdue University

West Lafayette, Indiana

Oral Mehmed

National Aeronautics and Space Administration

Lewis Research Center

Cleveland, Ohio

and

G.V. Narayanan

Sverdrup Technology, Inc.

NASA Lewis Research Center Group

Cleveland, Ohio

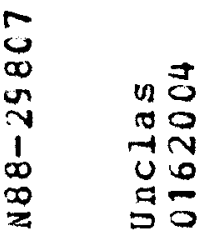

यु

电的

$2 \pi$

缩

भु

मis

$-$

$\underset{4}{4}$

다용

4 or

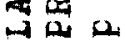

(is

0 난

a $N$

(4)

$\approx \Omega$

$\omega$

$-40$

$\neq 0 \leq$

in

0.9

02

Prepared for the

24th Joint Propulsion Conference

cosponsored by the AIAA, ASME, SAE, and ASEE

Boston, Massachusetts, July 11-13, 1988

3) 


\author{
Krishna Rao V. Kaza* \\ National Aeronautics Space Administration \\ Lewis Research Center \\ Cleveland, Ohio 44135 \\ Marc H. Williams ${ }^{\dagger}$ \\ School of Aeronautics and Astronautics \\ Purdue University \\ West Lafayette, Indiana 47907 \\ Oral Mehmed \\ National Aeronautics Space Administration \\ Lewis Research Center \\ Cleveland, Ohio 44135 \\ G.V. Narayanan \\ Sverdrup Technology, Inc. \\ NASA Lewis Research Center Group \\ Cleveland, $\mathrm{OH} 44135$
}

\begin{abstract}
An analytical investigation of aeroelastic response of metallic and composite propfan models in yawed flow has been performed. The analytical model is based on the normal modes of a rotating blade and the three-dimensional unsteady lifting surface aerodynamic theory including blade mistuning. The calculated blade stresses or strains are compared with published wind tunnel data for two metallic and three composite propfan wind tunnel models. The comparison shows a good agreement between theory and experiment. Additional parametric results indicate that blade response is very sensitive to the blade stiffness and also to blade frequency and mode shape mistuning. From these findings, it is concluded that both frequency and mode shape mistuning should be included in aeroelastic response analysis. Furthermore, both calculated and measured strains show that combined blade frequency and mode shape mistuning has beneficial effects on response due to yawed flow.
\end{abstract}

\title{
INTRODUCTION
}

Renewed interest in propfan (or advanced turboprop) propulsion is due to its potential for very high fuel efficiency at cruise speeds up to Mach 0.85 . A number of studies have been conducted by both NASA and industry to evaluate the potential of propfan propulsion for both civil and military applications. These studies have led to two promising propfan concepts: One is single rotation (SR) with eight to ten blades and the other is counterrotation (CR). Both these concepts have been extensively studied. Large scale models have been built, and flight-tested (refs. I and 2) for proof of concept.

* Senior Research Engineer; Associate Fellow, AIAA.

†rofessor; Member AIAA.

Research Engineer; Member AIAA, ASME.

§Project Engineer. 
Supporting these new propfan concepts, both theoretical and experimental research effort on propfan aeroelasticity has been continuing at NASA Lewis Research Center. As a part of this research, a theoretical investigation on forced aeroelastic response of SR propfans in yawed-or off-axis flow has been performed. The yawed flow causes a periodic change in the angle of attack of blades, and this change, in turn, causes one per revolution periodic loading on the blades. Understanding and predicting this kind of periodic loading and the propfan blade response are very important in the design of the blades.

Theoretical prediction of propfan aeroelastic response is one of the most challenging problems faced by aeroelasticians because the blades are thin and flexible with large sweep. The deflections due to centrifugal and aerodynamic loads are large, particularly at the blade tip; hence the response problem is inherently nonlinear requiring geometric nonlinear theory of elasticity in structural modeling of the blades. Since the blades have a moderate aspect ratio with large sweep, three-dimensional aerodynamic effects in addition to cascade effects should be included in the aerodynamic modeling of the blades. Additionally, the properties of the blades differ from blade to blade because of manufacturing limitations. The presence of such small differences is known as mistuning and it is expected to play a significant role on the blade aeroelastic response. Because of these complexities, published literature on the propfan forced response is very limited. References 3 and 4 calculated the forced response of three propfan wind tunnel models tested at NASA Lewis. Analysis was based on two-dimensional unsteady aerodynamic theory without blade mistuning. The correlation between theory and experiment varied from poor to good and identified a need for improved analys is methods.

The specific objectives of the present investigation are: (1) to improve the propfan forced response prediction capabilities by developing a theoretical model, and an associated computer program, with three-dimensional unsteady aerodynamic effects and aerodynamic and structural mistuning; (2) to correlate theoretical and experimental results for validating the analysis; and ( 3 ) to conduct parametric studies to assess the effect of frequency and mode shape mistuning on blade response.

To accomplish these objectives, the theoretical aeroelastic models described in references 5 and 6 were enhanced to calculate blade stresses due to yawed flow. As in references 5 and 6 , each blade was structurally modeled by using plate finite elements. The three-dimensional, unsteady subsonic lifting surface aerodynamic theory, described in reference 7 , was extended to account for blade mistuning and for yawed flow. The aerodynamic theory was also extended to cover supersonic helical Mach numbers with subsonic axial flow. By using blade normal modes and the associated unsteady aerodynamic loads, a modal forced response analys is and an associated computer program, ASTROP3, were developed. The acronym ASTROP3 stands for, "Aeroelastic Stabi1ity and Response of Propulsion Systems."

The code was applied to five wind tunnel propfan research models of $0.62 \mathrm{~m}$ $(2 \mathrm{ft})$ diameter which were tested for forced response at NASA Lewis. These mode ls are SR-5 (ref. 8), SR-3 (ref. 4) SR3C-X2 (ref. 5), SR3C-3 (ref. 6), and SR3C-X2/SR3C-3 (ref. 6). The blades of the first two models were made of titanium, and of the last three models were molded from graphite-ply/epoxy-matrix laminated material. The blade mistuning in the first four models was inherent from manufacturing tolerances and was relatively small. However, the fifth model was intentionally mistuned for a particular type of mistuning which is 
characterized by the differences in the blade frequencies, mode shapes, steadystate deflected shapes, and motion dependent unsteady aerodynamic loads.

The paper presents the analytical development of an aeroelastic response model, outlines the application of the analysis to the wind tunnel models, and correlates calculated and measured blade stresses. Finally, the paper presents some results to show the effects of mistuning on the aeroelastic response of the propfan models.

\section{NOMENCLATURE}

[A]

$\left[\mathrm{A}_{1}\right]$

$\{d A\}$

$[E],\left[\bar{E}_{S, r}\right]$

$\left\{F_{O}\right\}$

$f_{j}$

\{G\}

[I]

i

$\left[K_{g}\right]$

$\left[K_{i}\right]$

$\left[K\left(\left\{u_{0}\right\}\right)\right]$

$\left[K_{S}\right]$

[ $\left.\ell_{r}\right]$

M

[M]

$\left[M_{g}\right]$

$\left[M_{j}\right]$

$M_{i j}$

NG

NB matrix of influence coefficients, equation (5)

generalized aerodynamic matrix

area vector, equation (6)

matrices, equations (10) and (11)

nonaerodynamic force vector of a group of blades

modal frequency of a blade in $\mathrm{jth}$ mode, $\mathrm{Hz}$

generalized aerodynamic force vector due to yawed flow unit matrix

$\sqrt{-1}$; also blade index

generalized stiffness matrix of a group of blades

generalized stiffness matrix ith blade in a group

stiffness matrix of a group of blades, equation (1)

centrifugal softening matrix of a group of blades

aerodynamic matrix, $r=0,1 \ldots N G-1$, equation (8)

Mach number of freestream

physical mass matrix

generalized mass matrix of a group of blades

generalized mass matrix of a jth blade

generalized mass of $i$ th blade in $j$ th mode

number of blade groups

number of blades in a group 
number of modes of a group

NP

NMi

NRT

$[P]$

$\left\{P\left(\left\{u_{0}\right\}\right)\right\}$

$\{q\}$

$\left\{q_{0}\right\}$

$q_{i j}$

$\left[S_{j}\right]$

$\left\{u_{0}\right\}$

$[W]$

Bo. 75R

$\{\Delta \mathrm{u}\}$

$[\delta]$

$\zeta i j$

$\sigma_{G} \mathfrak{i}$

$\sigma_{x x i}, \sigma_{y y i}, \sigma_{x y i}$

$\left[\phi_{j}\right]$

$\omega i j$ number of aerodynamic panels in a group

number of modes of the ith blade in a group

total number of panel edge radi $i$ in a group

aerodynamic loads of a blade group

steady-state aerodynamic modal force vector of a group of

blades

generalized coordinate vector of a blade group

complex amplitude of $\{q\}$

generalized coordinate of the $j$ th mode of the $i$ th blade

in a group

modal stress matrix of an element of the ith blade

steady-state deflection

matrix of normal velocities

blade pitch angle at $3 / 4$ radius

vibratory deflection vector at grid points

normal displacement of the blade surface at the control points damping ratio in $j$ th mode of the ith blade in a group intergroup phase angle between like blades from group to group normal and shear stresses of an element of the $i$ th blade modal matrix of ith blade in a group

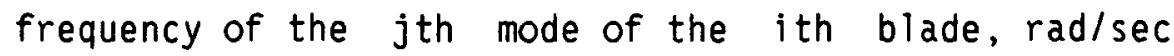

FORMULATION OF ANALYTICAL MODEL FOR AEROELASTIC RESPONSE

An analytical model for flutter and forced response by the modal method for tuned single-rotation propfans with rigid hubs was presented in reference 5. That model was extended and generalized in reference 6 for flutter of single rotation propfans with structurally and aerodynamically mistuned blades. Effects of the aerodynamic mistuning on the propfan flutter (including alternately mounted backward and forward swept blades) were addressed in reference 9. In this section, the model presented in reference 6 has been extended and generalized for aeroelastic response of SR propfans in yawed flow. Since the basic details were given in references 5 and 6 , only an outline of the 
development and of special modifications which are essential to incorporate both aerodynamic and structural mistuning are presented here.

\section{Equations of Motion for Aeroelastic Response of a Mistuned Propfan}

The propfan, shown in figure 1 , is assumed to have NG identical groups of blades symmetrically distributed around the disk. Each group contains NB blades which need have no special geometric or spatial relationship to each other. A schematic for an eight-bladed rotor with four blade groups is illustrated in figure 2. A tuned rotor then corresponds to $N B=1$, in which case $N G$ is the total number of blades. In general, it is assumed that the groups vibrate with identical motion, but with a constant intergroup phase angle, which may take any of the values $\sigma_{G i}=2 \pi i / N G, i=0,1, \ldots(N G-1)$. Generalizing the steady-state single blade equation in reference 5 , the corresponding equation for any group is

$$
\left.\left[K_{s}\right]+\left[K\left(\left\{u_{0}\right\}\right)\right]\right]\left\{u_{0}\right\}=\left\{P\left(\left\{u_{0}\right\}\right)\right\}+\left\{F_{0}\right\}
$$

The form of equation (1) is the same as the corresponding one in reference 5 , but the orders of the matrices and of the displacement vector are different. The stiffness and force matrices in equation (1) represent the entire blade group. For example, for a propfan with eight blades (four groups with two blades in each group), 228 grid points for each blade, and six degrees of freedom for each grid point, the total number of degrees of freedom of equation (1) is 2736. Furthermore, the equation is nonlinear involving large deflections, centrifugal loads, and steady-state airloads. The solution requires substantial computer time. To reduce that time, the steady-state aerodynamic loads have been neglected herein (the effect of these steady airloads on flutter for a tuned rotor is addressed in ref. 5). With this assumption, the steady aerodynamic coupling between the blades in a group is eliminated from the analysis. Consequently, the steady-state deflections and the differential stiffness of each blade in a group can be calculated independently by using equation (1) without steady airloads. The computational proceure used for both the metali ic and composite blades is the same as that described in reference 5. The vibration modes and frequencies of each blade in the group are calculated independently by using the following equation, which is also discussed in reference 5 .

$$
\text { [M] }\{\Delta \ddot{u}(t)\}+\left[\left[K_{s}\right]+\left[K\left(\left\{u_{o}\right\}\right)\right]\right]\{\Delta u(\{t)\}=0
$$

For calculating the blade elemental stresses and strains, the blade modal stresses are required. In solving equation (2), the modal stresses are also calculated. The next step in the formulation of the aeroelastic model by the modal method is to generalize the single blade equation of reference 5 to NB blades in a group. Assuming simple harmonic motion and following the procedure in reference 6 , the aeroelastic equations for NB arbitrarily mistuned blades in a group are

$$
\left[M_{g} J\{\ddot{q}\}+\left[K_{g} J\{q\}=\left[A_{1}\right]\{q\}+\{G\} e^{i \omega t}\right.\right.
$$

Again, the form of equation (3) is the same as the corresponding one of reference 5 , but the orders of the matrices and of the generalized coordinate vector are different. The new definitions are as follows: 


$$
\begin{aligned}
& P M_{g} J=\left[\begin{array}{llll}
E M_{1} J & & \\
& {\left[M_{2} J\right.} & \\
& & \ddots & \\
& & & E M_{N B} J
\end{array}\right] \\
& \nabla K_{g} J=\left[\begin{array}{llll}
E K_{1} J & & \\
& \nabla K_{2} J & \\
& & \ddots & \\
& & & E K_{N B} J
\end{array}\right] \\
& \{q\}=\left\{\begin{array}{c}
\left\{q_{1}\right\} \\
{\left[q_{2}\right\}} \\
\vdots \\
{\left[q_{N B}\right\}}
\end{array}\right\} \\
& \forall M_{i} J=\left[\begin{array}{llll}
M_{i 1} & & & \\
& M_{i 2} & & \\
& & \ddots & \\
& & & M_{i N M i}
\end{array}\right] \\
& E K_{i} J=\left[\begin{array}{c}
M_{i 1} \omega_{i 1}^{2}\left(1+2 i \zeta_{i 1}\right) \\
M_{i 2} \omega_{i 2}^{2}\left(1+2 i \zeta_{i 2}\right) \\
\ddots \\
M_{i N M i}{ }_{i N M i}^{2}\left(1+2 i \zeta_{i N M i}\right)
\end{array} \mid\right. \\
& \left\{\mathbf{q}_{i}\right\}=\left\{\begin{array}{c}
\left\{\mathbf{q}_{i 1}\right\} \\
\left\{\mathbf{q}_{i 2}\right\} \\
\vdots \\
\left\{\mathbf{q}_{i N M i}\right\}
\end{array}\right\} \\
& {\left[\Delta u_{i}(t)\right\}=\left[\phi_{i}\right]\left[q_{i}\right\}}
\end{aligned}
$$


The coefficients $M_{i j}, \omega_{i j}$, and $\zeta_{i j}$ are the generalized mass, the frequency, and the damping ratio, respectively, corresponding to the $j$ th normal mode of the ith blade in a group. The suffix NMi represents the number of blade normal modes considered for the $i$ th blade in the analysis. The quantities $\left[\phi_{i}\right]$ and $\left\{q_{j}\right\}$ are the modal matrix and the generalized coordinate vector for the $i$ th blade in a group, respectively. The details for the development of the motion dependent aerodynamic matrix, $\left[A_{1}\right]$, and the motion independent aerodynamic matrix, $\{G\}$, are given in the following section.

\section{Unsteady Aerodynamic Model For Arbitrary Mistuning}

The generalized aerodynamic force matrix, $\left[A_{j}\right]$, in equation (3) has been computed with the three-dimensional compressible lifting surface theory described in reference 7 . Since the extension of the theory to include mistuning is given in reference 6 , only an outline of the method and special modifications for calculating the aerodynamic matrix, $\{G\}$, will be discussed.

The numerical method is based on an assumed linearization of the fluid motion about a uniform steady flow. The disturbance generated by the rotor blades is presumed to be simple harmonic in time in a reference frame rotating with the blades. Each wake is assumed to be rigid and to lie in the helical surface swept out by the blade trailing edge. These assumptions result in a linear integral equation relating the normal velocity of the surface of the blades to the load (differential pressure) acting on the blades. The integral equation is solved by a piecewise constant load panel method.

For simplicity, the effects of hubs and nacelles are ignored, as is blade thickness. The blades are, in effect, treated as loaded helical surfaces with no thickness. As in any linear aerodynamic theory, the unsteady loads induced by blade vibration are mathematically decoupled from the steady loads arising from blade incidence.

The use of linear aerodynamic theory limits the applicability of the method to lightly loaded conditions (unstalled) and to Mach numbers at which transonic effects at the blade tips are not significant. In addition, the rigid wake approximation breaks down at low advance ratios, where the induced velocities may have a strong influence on the wake structure (which in turn may significantly modify the blade loading). Of course, one usually does not know apriori whether such effects will be present at a given operating point, so some caution in interpreting the results is necessary.

The geometry and vibration mode data are usually obtained by solving equations (1) and (2) with COSMIC NASTRAN (ref. 10). For aerodynamic modeling, the group is paneled by placing a fixed number, NXP, of quadrilateral panels on each radial interval $r t(j)<r<r t(j+1), j=1, \ldots$ NRT (unless $r t(j+1)<r t(j)$, which signals a jump from the tip of one blade to the root of the next). Thus, except for the deletion of tip-root connections, the group is effectively treated as a single surface with NP $=$ NXP* (NRT - NB) panels.

The definition of group vibration modes requires special mention. Essentially, one group mode consists of one blade in the group vibrating in one of its natural modes while all other blades in the group remain fixed. Suppose the $j$ th blade in a group is assigned $N M j$ vibration modes. The group as a whole, then has NMG $=$ NMI + NM2 $+\ldots+$ NMNB modes. The group mode NMI +1 , 
for example, corresponds to the second blade in the group vibrating in its first mode, while all remaining blades are stationary.

In general, let matrix $[W(n, k)]$ denote the normal velocity at the $n$th control point, the point at which the boundary condition is enforced, in the $k$ th group mode. This array is initialized to zero and then loaded sequentially with the NMI values of first blade modes $\left[\phi_{1}\right]$, at control points on the first blade, the NM2 values of second blade modes, $\left[\phi_{2}\right]$, at control points on the second blade, and so on. The normal velocities at each control point due to the yawed flow are stored in the last column of the [W] matrix. Thus the total number of rows of the [W] matrix is equal to the number of control points in the group, and the total number of columns is equal to $N M G+1$.

problem:

The aerodynamic loads can then be found by solving the linear algebra

$$
[A][P]=[W]
$$

where [A] is the (NP,NP) matrix of influence coefficients, [W] is the (NP, $N M G+1)$ matrix of normal velocities, and $[P]$ is the (NP, NMG + 1) array of loads on the blade group. The influence coefficient matrix contains the interference between blade groups and, therefore, depends on the intergroup phase angle (as well as the vibratory frequency). Thus, separate solutions are required for every intergroup phase angle and frequency of interest. For example, for an eight-bladed propfan with tuned blades, the intergroup phase angle of the forcing function is $315^{\circ}$, which corresponds to a one nodal diameter backward traveling wave. For an eight-bladed propfan with four symmetrically identical groups, the intergroup phase angle of the loading is $270^{\circ}$.

Once the load distribution has been found, the generalized force matrix can be determined by numerical integration over the blade group:

$$
A_{1}(n, m)=\sum_{j=1}^{N P} P(j, m) \delta(j, n) d A(j)
$$

where $P(j, m)$ is the load on the $j$ th panel (with area $d A(j)$ ), associated with the mth group mode, and $\delta(j, n)$ is the normal displacement of the surface at the control point of the $j$ th panel in the $n$th mode. Also, the aerodynamic force matrix due to yawed flow is

$$
G(n)=\sum_{j=1}^{N P} P(j, N M G+1) \delta(j, n) d A(j)
$$

The matrices $\left[A_{1}\right]$ and $\{G\}$ can be calculated for any given frequency of oscillation and any given intergroup phase angle. However, for yawed flow the frequency of the aerodynamic loading on the blade is the same as the rotational frequency of the propfan and the intergroup phase angle of the loading is $2 \pi(N G-1) / N G$.

The above formulation (eq. (3)), is valid for an arbitrarily mistuned propfan. Also in this case, the entire rotor has to be modeled for calculating 
the aerodynamic loads. For example, for a propfan with eight unidentical blades with 72 aerodynamic panels for each blade, the total number of panels in equations (5) and (6) is 576.

\section{Unsteady Aerodynamic Model for Frequency Mistuning}

If the vibration mode shapes of all the blades are identical, and if only the differences in blade vibration frequencies around the rotor are to be accounted for, the computational time and the computer memory required for calculating the matrices, $\left[A_{l}\right]$ and $\{G\}$, can be minimized by calculating the aerodynamic loads for each intergroup phase angle independently. For this special case the number of blades in a group, NB, equals one, and the intergroup and interblade phase angles are the same. Let the generalized aerodynamic and the forcing function matrices for the $r$ th interblade phase angle be [ $\ell_{r}$ ] and $\left\{g_{r}\right\}$ where $\left.r=0,1 \ldots(N G-1)\right)$. These matrices are calculated by using equations (6) and (7) and by paneling only one blade. For yawed flow, the matrix $\left\{g_{r}\right\}$ has to be calculated only for $r=N G-1$. Then for the case of arbitrary frequency mistuning the matrices, $\left[A_{1}\right]$ and $\{G\}$ can be

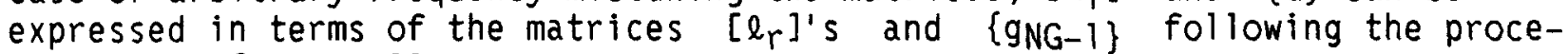
dures in reference 11 as

$$
\begin{gathered}
{\left[A_{1}\right]=[E]\left[\begin{array}{ccc}
{\left[l_{0}\right]} & & \\
& {\left[l_{1}\right]} & \\
& \ddots & \\
& & {\left[l_{N G-1}\right]}
\end{array}\right][E]^{-1}} \\
\{G\}=[E]\left\{\begin{array}{c}
\left\{g_{0}\right\} \\
\left\{g_{1}\right\} \\
\vdots \\
\left\{g_{N G-1}\right\}
\end{array}\right\}
\end{gathered}
$$

where

$$
\begin{aligned}
& {[E]=\left[\begin{array}{cccc}
{\left[\bar{E}_{0,0}\right]} & {\left[\bar{E}_{0,1}\right]} & \cdot \\
\vdots & & \\
\cdot & \cdot & & {\left[\bar{E}_{N G-1, N G-1}\right]}
\end{array}\right]} \\
& {\left[\bar{E}_{s, r}\right]=e^{i(2 \pi r s / N G)}[I], \quad s=0,1,2 \ldots . N G-1}
\end{aligned}
$$


For simple harmonic motion

Equation (3) leads to the following

$$
\{q\}=\left\{q_{0}\right\} e^{i \omega t}
$$

$$
\left\{q_{0}\right\}=\left[-\omega^{2}\left[M_{g} J+\left[K_{g}\right]-\left[A_{1}\right]\right]^{-1}\right.
$$

The amplitude of generalized coordinate vector is calculated for a given flow Mach number, yaw angle, rotational speed, and blade setting angle by extending the computer program, ASTROP3, described in reference 5 .

\section{Calculation of Blade Stresses and Strains}

The blade deflected shape and vibration data (modes, frequencies, generalized masses, and modal stresses) have been obtained by solving equations (1) and (2). with NASTRAN code. From the modal stresses and the amplitude of the generalized coordinate vector, the elemental stresses have been calculated by using the relation

$$
\left\{\begin{array}{l}
\sigma_{x x i} \\
\sigma_{y y i} \\
\sigma_{x y i}
\end{array}\right\}=\left[s_{i}\right]\left\{q_{o i}\right\}
$$

where $\sigma_{x x i}, \sigma_{y y} i$ and $\sigma_{x y} i$ are the two normal stresses and the shear stress of an element of the $i$ th $b$ lade in the blade local coordinate system; [S $S_{j}$ is the modal stress matrix of an element of the ith blade; and $\left\{q_{0 i}\right\}$ is the amplitude of the generalized coordinate vector for the ith blade. For comparison with stresses measured on the metallic blades, the elemental stresses are resolved along and perpendicular to the strain gage direction. The resolved stresses of the elements surrounding the strain gages were averaged to calculate a value at the gage location. For comparison with strains, measured on the composite blades, the strains at the gage locations are calculated by averaging the resolved elemental strains of the surrounding elements. The elemental strains are, in turn, calculated from the elemental stresses and the equivalent material properties of the elements.

\section{RESULTS AND DISCUSSION}

The analytical model and the ASTROP 3 code were applied to five wind tunnel models of $0.62 \mathrm{~m}(2 \mathrm{ft})$ diameter which were tested for aeroelastic response in yawed flow at NASA Lewis. These models are: (1) SR-5 with ten titanium blades; (2) SR-3 with eight titanium blades; (3) SR3C-X2 with eight composite blades consisting of 80 percent of the plys along the blade pitch axes and 20 percent along the $\pm 22.5^{\circ}$ directions; (4) SR $3 C-3$ with eight composite blades consisting of 80 percent of the plys along the blade pitch-axis and 20 percent along the $\pm 45^{\circ}$ directions; and (5) SR3C-X2/SR3C-3 with four SR3C-X2 blades and 
four SR3C-3 blades mounted alternately (for both frequency and mode shape mistuning). These five models were experimentally tested for aeroelastic response in yawed flow at different Mach numbers, rotational speeds, and blade setting angles. The data have been documented in reference 4 for SR-3 and SR-5, and in reference 12 for SR3C-X2, SR3C-3 and SR3C-X2/SR3C-3. From this data bank, only selected test points were chosen to analyze and validate the analytical aeroelastic response model and the ASTROP 3 code. The results are presented in eight parts: (1) Analysis cases; (2) calculated and measured nonrotating blade frequency table; (3) calculated rotating blade frequency table; (4) calculated and measured blade stress amplitudes for SR-5; (5) Variation of the SR-5 blade stress with the blade stiffness and mistuning; (6) Variation of the SR-5 blade stresses with the number of blades (7) calculated and measured stress amplitudes for the SR-3; and (8) calculated and measured strain amplitudes for the SR3C-X2, SR3C-3

and SR3C-X2/SR3C-3.

In all of the calculations, the frequencies and mode shapes of the blades were obtained by using COSMIC NASTRAN. The steady-state deflected position of the blade due to centrifugal loading is employed in calculating both vibration and aeroelastic response. The structural damping of the blades is not included in the calculations. Also for unsteady aerodynamic calculations, each blade is discretized with nine (radial) by eight (chordwise) panels.

\section{Analysis Cases}

Cases considered for analysis are listed in table 1. Four cases each for the SR-5 and SR-3 models (covering four rotational speeds, four Mach numbers, three blade setting angles and six propfan airflow angles) were chosen. These cases cover a wide range of operating conditions. Both the SR-5 and the SR-3 were chosen for analysis because the blade sweep of the SR-5 model blade is larger than that for the SR-3. Also, the number of blades of the SR-5 propfan is ten and that of the SR-3 is eight. For the three composite propfan models, one test tunnel condition was chosen in order to validate the code with the effects of blade ply directions and of both blade frequency and mode shape mistuning on aeroelastic response due to yawed flow.

\section{Calculated and Measured Nonrotating Blade Frequencies}

For the five cases considered, calculated and measured nonrotating blade frequencies are tabulated in table 2 . The average values of the measured frequencies are listed. Only the frequencies for the first four modes are listed in this table since the higher order modes are not important, as will be discussed, for forced response due to yawed flow. However, for one of the test cases of the SR-5 blade, the effect on blade response of using up to six modes is investigated. The measured blade frequencies of each propfan model differ slightly from each other because of manufacturing tolerances. Comparing the calculated and measured frequencies, the agreement is satisfactory for the first two modes and is poor for the third and fourth modes. Although not shown, the qualitative agreement between the calculated and measured first and second mode shapes is also good. More detailed discussions are presented in references 5 and 6 . 


\section{Calculated Rotating Blade Frequencies}

The rotating blade frequencies for the first four modes, for each blade and for each test point, are listed in table 3 . The frequencies are calculated with centrifugal stiffening and softening loads by using COSMIC NASTRAN. The effects of hub flexibility are neglected in modeling the blade and, hence, there is no structural coupling between the blades. Also, Coriolis forces introduced by rotation are not included because they were shown to be negligible for the propfan blades in reference 13. Detailed discussion on correlation between calculated and measured frequencies can be found in references 4 , 5,6 , and 8 . This comparative table is included in this paper in order to show that the excitation frequency due to yawed flow, which is the blade rotational frequency, shown in table 3 , is placed well below the first mode frequency. The importance of this will be discussed in the next section.

\section{SR-5 Calculated and Measured Blades Stresses}

The calculated stress amplitudes for the four test point cases of the SR-5 propfan model are compared with the measured ones in table 4 . Only the amplitudes are compared because the interblade phase angle of the calculated stress for the tuned rotor is $324^{\circ}\left(-36^{\circ}\right)$ which corresponds to a one nodal diameter backward traveling wave. The predominant interblade phase angle measured is also $324^{\circ}$. Average values of the calculated normal (along the strain gage axis) and shear (plane perpendicular to the strain gage axis) stresses of the blade finite elements neighboring a strain gage location are tabulated in table 4 .

In calculating the blade stresses, a numerical convergence study was conducted by varying the number of modes for the test point case 8508 . This study, although the results are not shown here, showed that the major contribution to blade stresses comes from the first two modes (about 75 percent from the first mode and the remaining from the second mode.) The contribution from the higher modes is negligible. This was expected because the excitation frequency of the forcing function due to yawed flow is the same as the rotational frequency and is well below the first mode frequency of the blade at that rotational speed. Because of this finding, only two normal modes are used for calculating the stresses listed in table 4 .

The blade stresses are measured at four locations which are shown in figure 3. Also included in this figure are strain gage angles measured with respect to pitch axis and the radial and chordwise locations of strain gages. Gages 1, 5, and 6 measured normal stresses and gage 3 measured shear stresses.

To give a graphical picture of the correlation between theory and experiment, calculated and measured stresses for the four test cases are shown in figures 4 to 7 . The variation of the calculated stress around a strain gage is illustrated by a vertical bar in these figures.

For the test point cases 8508,8511 and 8610 , the correlations in figures 4,5 , and 7 , respectively, are good. The calculated stresses are lower than the corresponding measured values. This may be due to the level of blade frequency and mode shape mistuning (which usually have adverse effect on response), discrepancies in strain measurements, strain gage orientations, or the finite element model. The correlation between theory and experiment for 
the test point case 8607 ( $f$ ig. 6 ) is not as good as that in figures 4 , 5, and 7, particularly for strain gage 6 . This may be due to the fact that the inflow (or yaw) angle is $12^{\circ}$ which is significantly higher than $2^{\circ}, 5^{\circ}$, and $3^{\circ}$ for the cases 8508,8511 , and 8610 , respectively. For this high inflow angle, the assumption of attached flow may break down.

\section{Variation of SR-5 Blade Stresses with Blades Stiffness and Mistuning}

It is well known that the blade stresses are functions of the blade stiffness and blade mistuning. A decrease in the blade stiffness increases the blade stresses. However, the effect of blade mistuning may have either a beneficial or an adverse effects on blade vibratory response and hence on the blade stresses. To illustrate the sensitivity of blade stress due to variation in stiffness and type of mistuning, the calculated results of a parametric investigation employing the SR-5 propfan test point case 8508 are 1 isted in table 5. The model in case $8508-R$ is the reference rotor with frequencies $f_{1}=140 \mathrm{~Hz}$ and $f_{2}=274 \mathrm{~Hz}$, for the first and second modes, respectively. For models in cases 8508-1 and 8508-2, the frequencies of all of the blades are reduced by 5 percent and are increased by 5 percent, respectively. A 5 percent reduction in blade frequency increased the blade stress from $1886 \times 10^{4}$ to $2196 \times 10^{4} \mathrm{Nm}^{-2}$, and a 5 percent increase in blade frequency decreased the blade stress from $1886 \times 10^{4}$ to $1640 \times 10^{4} \mathrm{Nm}^{-2}$. This clearly shows that the accuracy of the blade frequency calculation is very important for predicting blade stress even at the off-resonance condition.

The effect of blade alternate frequency mistuning on blade stresses is shown in case 8508-3. The frequencies of the odd blades are decreased by 5 percent and those of the even blades are increased by 5 percent. The blade stresses are calculated at the strain gage location 1 of blades 1 and 2 . Comparing stresses for the cases $8508-R$ and $8508-3, a \pm 5$ percent frequency mistuning has increased the blade stress from $1886 \times 10^{4}$ to $2181 \times 10^{4} \mathrm{Nm}^{-2}$ for blade 1 and has reduced from $1886 \times 10^{4}$ to $1651 \times 10^{4} \mathrm{Nm}^{-2}$ for blade 2. However, comparing stresses for the cases 8508-1 to 8508-3, a \pm 5 percent frequency mistuning has not increased the stresses significantly.

The worst case of mistuning is the one where a "rogue blade" is present. In this case, all but one of the blades are identical. To quantify this fact for propfan blades, four cases 8508-4 to 8509-7 are considered. The frequencies of blade 1 are varied from 0.95 to 1.1 times the reference values, $f$, and $f_{2}$. Comparing the stresses on blade 1 at strain gage location 1 , there is a significant change in blade stress from $2550 \times 10^{4} \mathrm{Nm}^{-2}$ for the case $8505-4$, to $1436 \times 10^{4} \mathrm{Nm}^{-2}$ for the case 8508-7. This comparison clearly demonstrates the importance of quality control in manufacturing the blade and the role of blade mistuning in aeroelastic response analysis.

\section{Variation of SR-5 Blade Stresses with Number of Blades}

Table 6 shows variation of blade stress with number of blades. Evidently, the blade stress increases, with a decrease in number of blades. It should be noted that with a decrease in number of blades, the interblade phase angle of the forcing function is changing even though the frequency is the same. For example, the interblade phase angle is $324^{\circ}$ for ten blades, $315^{\circ}$ for eight blades, $300^{\circ}$ for six blades and so on. It is also noted from the results that 
the two lowest damped interblade phase angles for the ten bladed case are $288^{\circ}$ and $324^{\circ}$ which corresponds to two and one nodal diameter backward traveling waves, respectively. As the number of blades decreases, the damping of the one nodal diameter backward traveling wave mode increases. Also, the amplitude of the forcing function increases with a decrease in the number of blades. This is because closer blade spacing causes a reduction in blade lift from the induced velocity. Thus, the increase in blade response with a decrease in number of blades is not surprising, even though it is not obvious.

\section{SR-3 Calculated and Measured Blade Stresses}

Table 7 compares calculated and measured stress amplitudes for the four test point cases of the SR-3 propfan model. For this eight-bladed rotor, the interblade phase angle of the calculated stress for the tuned rotor is $315^{\circ}$, which corresponds to a one nodal diameter backward traveling wave. The predominant interblade phase angle measured is also $315^{\circ}$, but there is a slight deviation from this angle because of the presence of a small amount of blade frequency mistuning. Average values of the calculated normal and shear stresses of the blade finite elements neighboring a strain gage location are tabulated.

The blade stresses are measured at five locations which are shown in figure 8. Gages 1, 2, 3, and 5 measured normal stress and gage 4 measured shear stress.

For a graphical comparison, the calculated and measured stresses for one test case, point 190, are plotted in figure 9. The results show that the correlation between theory and experiment is good. In the case of SR-5, the calculated stresses are lower than the measured ones, whereas in the case of SR-3, the calculated stresses for some gages are higher and for some gages lower than the measured ones.

Comparing the present correlation between theory and experiment with that in reference 3, where a two-dimensional aerodynamic theory was used, the general trend is the same but the present correlation is slightly better in some cases, which should be expected from a more refined three-dimensional aerodynamic model. But, with a three-dimensional aerodynamic model, the uncertainties associated with a two-dimensional model, such as the choice of reference axis for measuring blade sweep and the validity of sweep correction, do not arise.

Calculated and Measured Blade Strains for the SR3C-X2, SR3C-3, and SR3C-X2/SR3C-3 Propfans

To validate the present analytical formulation and ASTROP3 for the prediction of blade stresses of composite blades with mistuning, three composite propfan models were studied. The calculated and measured flutter data of these models were presented in reference 6 , and the measured aeroelastic response data were presented in reference 12. All three models are now analyzed for aeroelastic response at one set of wind tunnel conditions: $M=0.36$, $\mathrm{rpm}=5500, \beta_{0} .75 \mathrm{R}=48^{\circ}$. The calculated and measured strains are compared in table 8 at two strain gage locations which are shown in figure 10 . For these 
cases, strains are compared instead of stresses, because the measured data were in this form.

SR3C-X2 correlation. - The variation of the SR3C-X2 blade natural frequencies with rotational speed, and a comparison of measured bench natural frequencies with corresponding calculated ones were presented in reference 5 . Since the correlation between theory and experiment, as discussed in reference 5 , is poor for the second mode, three subcases of calculated strains are presented in table 8. In the subcase "a", calculated frequencies are used; in the subcase " $b$ ", the measured second mode frequency is used; and in subcase "c", the "quasi-measured" rotating frequencies are used for the first mode and measured nonrotating frequency for the second mode for each blade. The quasi-measured frequencies are obtained from the nonrotating measured frequencies with a correction to centrifugal stiffening and softening loads. The correction is based on Southwell coefficient which is determined from the blade rotating and nonrotating calculated frequencies. No correction was applied to the second mode frequency because it does not change appreciably with rotational speed. Essentially, subcase "c" represents a rotor with an arbitrary frequency mistuning.

Comparing the measured and calculated strains, in subcase "a" for the SR3C-X2 model, the measured values at the strain gage location 1 are higher by 27.8 percent. However, correlation between the measured and calculated strains in subcases " $b$ " and " $c$ " is better than subcase "a", with the measured values still higher than the calculated by 17 percent. Evidently, this comparison shows the significance of the accuracy required in predicting natural frequencies and the level of frequency mistuning.

SR3C-3 correlation. - The variation of the SR3C-3 blade measured nonrotating frequencies is not available. The value in table 2 represents only one blade. Since the correlation between the measured and calculated nonrotating first mode frequency (table 2) is not that good, two sets of calculated strains are listed in table 8 . The subset "d" strain is with calculated first and second mode frequencies, and subset " $e$ " is with quasi-measured first mode rotating frequency. As can be seen, the calculated strain for the subsets " $d$ " and "e" are greater than the measured value, but the strain for subset "e" is closer to the measured value. Again, the calculated results are very sensitive to the first mode rotating frequency.

SR3C-X2/SR3C-3 correlation. - In view of the deviations (table 2) between the calculated and measured frequencies for the SR3C-X2 and SR3C-3 blades, two sets of calculated results, subcase "f" and subcase " $g$ ", are included in table 8. These cases represent an alternate mistuned rotor. The strain for subcase " $f$ " is based on the calculated frequencies and subcase " $g$ " is based on the quasi-measured frequencies. The measured and calculated strains for both the SR3C-X2 and SR3C-3 blades in the symmetric group are included. Contrary to the results in the subcases " $a$ " and " $d$ " in table 8 , the calculated strain in subcase " $f$ " is higher than the measured for the SR3C-X2 blade, but is lower than measured for the SR3C-3 blade. However, the correlation between theory and experiment in subcase " $g$ " with quasi-measured frequencies is better.

For all of the three models discussed earlier, the correlation between calculated and measured strains at strain gage location 2 is very poor. The reason for this is not known at this time of writing, and is under investigation. 
For the SR3C-X2 mode1, the calculated interblade phase angle is $315^{\circ}$, and the measured value varied from $312^{\circ}$ to $318^{\circ}$; for the SR3C-3 model the calculated value is $315^{\circ}$, and the measured value not available; and for the SR3C-X2/ SR3C-3 model the calculated value varied from $314^{\circ}$ to $316^{\circ}$, and the measured value varied from $308^{\circ}$ to $317^{\circ}$. The overall agreement between theory and experiment is good.

\section{CONCLUSIONS}

A theoretical aeroelastic response model was developed for predicting stresses and strains of metallic and composite propfan blades with blade mistuning. This model is based on normal modes of the rotating blades and threedimensional lifting surface unsteady aerodynamic theory. Calculated results were correlated with published measured strain or stress data for five wind tunnel propfan models. The correlations and additional parametric results led to the following conclusions:

1. Calculated and measured stresses or strains agree well in general. However, in most of the cases, the calculated values are lower than the measured values. Also, calculated and measured interblade phase angle of the blade response with and without blade mistuning agree well.

2. Calculated blade stresses and strains are very sensitive to the first mode frequency, as expected, since the excitation frequency is lower than the first mode blade frequency in all the cases analyzed. The first two blade normal modes are adequate to predict the response due to yawed flow.

3. Stresses and strains are also sensitive to the blade frequency and the mode shape mistuning. A \pm 5 percent alternate frequency mistuning does not have a significant adverse effect on blade stresses for the metallic blade (SR-5). But both frequency and mode shape mistuning have beneficial effects on composite blade strains due to yawed flow. These results demonstrate that both frequency and mode shape mistuning should be included in aeroelastic response analysis.

4. Calculated results showed that by increasing the number of blades on a rotor, a decrease in blade stress amplitudes due to yawed flow occurs.

\section{REFERENCES}

1. "Lockheed, GE Run Ultrahigh Bypass Engine Prototypes in Ground Tests," Aviation Week and Space Technology, Vol. 126, No. 17, Apr. 27, 1987, pp. 46-47.

2. Dornheim, M.A., "MCDonne11 Douglas UHB Demonstrator Flies with GE Unducted Fan Engine," Aviation Week and Space Technology, Vol. 126, No. 21, May 25, 1987 , pp. $32-\overline{35}$.

3. Elchuri, V., "Modal Forced Vibration Analysis of Aerodynamically Excited Turbosystems," NASA CR-174966, 1985. 
4. Smith, A.F., "Analysis and Test Evaluation of the Dynamic Response and Stability of Three Advanced Turboprop Models at Low Forward Speed," HSER-11055, Hamilton Standard, Windsor Locks, CT, Dec. 1985, NASA CR-175026, 1985.

5. Kaza, K.R.V., Mehmed, 0., Narayanan, G.V., and Murthy, D.V., "Analytical Flutter Investigation of a Composite Propfan Mode1," 28th Structures, Structural Dynamics and Materials Conference, Part 2A, AIAA, New York, 1987, pp. 84-97. (NASA TM-88944).

6. Kaza, K.R.V., Mehmed, 0., Williams, M., and Moss, L., "Analytical and Experimental Investigation of Mistuning in Propfan Flutter, "28th Structures, Structural Dynamics and Materials Conference, Part 2A, AIAA, New York, 1987, pp. 98-110. (NASA TM-88959).

7. Williams, M.H., and Hwang, C.C., "Three-Dimensional Unsteady Aerodynamics and Aeroelastic Response of Advanced Turboprop," 27th Structures, Structural Dynamics and Materials Conference, Part 2, AIAA, New York, 1986, pp. 116-124.

8. Mehmed, O., Kaza, K.R.V., Lubomski, J.F., and Kielb, R.E., "Bending-Torsion Flutter of a Highly Swept Advanced Turboprop," NASA TM-82975, 1981.

9. Williams, M.H., "Aeroelastic Effects of Alternate Blade Sweep on Advanced Propfan Rotor," ASME Paper 87-WA/AERO-8, Dec. 1987.

10. "The NASTRAN Theoretical Manual," NASA SP-221(06), 1981.

11. Kaza, K.R.V., and Kielb, R.E., "Flutter of Turbofan Rotors with Mistuned Blades," AIAA Journal, Vol. 22, No. 11, Nov. 1984, pp. 1618-1625.

12. Mehmed, O., and Murthy, D.V., "Experimental Investigation of Propfan Aeroelastic Response in Off-Axis Flow with Mistuning," AIAA Paper 88-3153, July 1988. (NASA TM-101320).

13. Subrahmanyan, K.B., Kaza, K.R.V., Brown, G.V., and Lawrence, C., "Nonlinear Bending Torsional Vibration and Stability of Rotating, Pretwisted, Preconed Blades Including Coriolis Effects," NASA TM-87207, 1986.

TABLE 1. - ANALYSIS CASE TABLE

\begin{tabular}{|c|c|c|c|c|c|c|c|c|c|}
\hline \multirow{2}{*}{$\begin{array}{c}\text { Propfan } \\
\text { model }\end{array}$} & \multirow[t]{2}{*}{ Test point } & \multirow{2}{*}{$\begin{array}{l}\text { Rota- } \\
\text { tional } \\
\text { speed, } \\
\text { rpm }\end{array}$} & \multirow{2}{*}{$\begin{array}{c}\text { Mach } \\
\text { number }\end{array}$} & \multirow{2}{*}{$\begin{array}{l}\text { Blade setting } \\
\text { angle, deg }\end{array}$} & \multicolumn{2}{|c|}{ Tunnei air density } & \multicolumn{2}{|c|}{ Speed of sound } & \multirow{2}{*}{$\begin{array}{l}\text { Inflow } \\
\text { angle, } \\
\text { deg }\end{array}$} \\
\hline & & & & & $\mathrm{kg} \mathrm{m}^{-3}$ & $1 b s^{-2} f t^{-4}$ & $\mathrm{~ms}^{-1}$ & in $s^{-1}$ & \\
\hline$S R-5$ & $\begin{array}{l}8508 \\
8511 \\
8607 \\
8610\end{array}$ & $\begin{array}{l}5500 \\
5500 \\
6000 \\
6000\end{array}$ & $\begin{array}{l}0.801 \\
.797 \\
.360 \\
.361\end{array}$ & $\begin{array}{l}70.8 \\
70.8 \\
60.8 \\
60.8\end{array}$ & $\begin{array}{r}0.9393 \\
.9438 \\
1.1883 \\
1.1886\end{array}$ & $\begin{array}{l}1.8225 \times 10^{-3} \\
1.8313 \\
2.3057 \\
2.3062\end{array}$ & $\begin{array}{l}329.8441 \\
330.0222 \\
339.0900 \\
339.0900\end{array}$ & $\begin{array}{ll}12 & 986 \\
12 & 993 \\
13 & 350 \\
13 & 350\end{array}$ & $\begin{array}{r}2 \\
5 \\
12 \\
3\end{array}$ \\
\hline SR-3 & $\begin{array}{l}190 \\
273 \\
277 \\
278\end{array}$ & $\begin{array}{l}8000 \\
8000 \\
7000 \\
8000\end{array}$ & $\begin{array}{l}.353 \\
.798 \\
.795 \\
.795\end{array}$ & $\begin{array}{l}48.9 \\
60.8 \\
60.8 \\
60.8\end{array}$ & $\begin{array}{r}1.2283 \\
.9010 \\
.9820 \\
.9823\end{array}$ & $\begin{array}{l}2.3833 \\
1.9034 \\
1.9053 \\
1.9060\end{array}$ & $\begin{array}{l}340.4108 \\
363.5502 \\
363.5502 \\
363.5502\end{array}$ & $\begin{array}{ll}13 & 402 \\
14 & 313 \\
14 & 313 \\
14 & 313\end{array}$ & $\begin{array}{l}8 \\
2 \\
4 \\
4\end{array}$ \\
\hline $\mathrm{SR} 3 \mathrm{C}-\mathrm{X} 2$ & 392 & 5500 & .36 & 48 & 1.1472 & 2.2260 & 355.3968 & 13992 & 8 \\
\hline$S R 3 C-3$ & 45 & 5500 & .36 & 48 & 1.1472 & 2.2260 & 355.3968 & 13992 & 8 \\
\hline $\begin{array}{r}S R 3 C-\times 2 / \\
\text { SR3C-3 }\end{array}$ & 768 & 5500 & .36 & 48 & 1.13744 & 2.2070 & 350.8248 & 13812 & 8 \\
\hline
\end{tabular}


TABLE 2. - CALCULATED AND MEASURED NONROTATING BLADE FREQUENCIES [Frequencies given in $\mathrm{Hz}$.]

\begin{tabular}{|c|c|c|c|c|c|c|c|c|}
\hline \multirow{2}{*}{$\begin{array}{c}\text { Propfan } \\
\text { model }\end{array}$} & \multicolumn{2}{|c|}{ Mode 1} & \multicolumn{2}{|c|}{ Mode 2} & \multicolumn{2}{|c|}{ Mode 3} & \multicolumn{2}{|c|}{ Mode 4} \\
\hline & $\begin{array}{l}\text { Calcu- } \\
\text { lated }\end{array}$ & $\begin{array}{l}\text { Meas- } \\
\text { ured }\end{array}$ & $\begin{array}{l}\text { Calcu- } \\
\text { lated }\end{array}$ & $\begin{array}{l}\text { Meas- } \\
\text { ured }\end{array}$ & $\begin{array}{l}\text { Calcu- } \\
\text { lated }\end{array}$ & $\begin{array}{l}\text { Meas- } \\
\text { ured }\end{array}$ & $\begin{array}{l}\text { Calcu- } \\
\text { lated }\end{array}$ & $\begin{array}{l}\text { Meas- } \\
\text { ured }\end{array}$ \\
\hline $\begin{array}{l}\text { SR-5 } \\
\text { SR-3 } \\
\text { SR3C-X2 } \\
\text { SR3C-3 }\end{array}$ & $\begin{array}{l}105 \\
167 \\
189 \\
170\end{array}$ & $\begin{array}{l}112 \\
160 \\
191 \\
188\end{array}$ & $\begin{array}{l}273 \\
411 \\
392 \\
419\end{array}$ & $\begin{array}{r}278 \\
385 \\
2371 \\
414\end{array}$ & $\begin{array}{l}515 \\
617 \\
700 \\
609\end{array}$ & $\begin{array}{l}483 \\
638 \\
693 \\
564\end{array}$ & $\begin{array}{l}634 \\
713 \\
752 \\
800\end{array}$ & $\begin{array}{l}631 \\
866 \\
987 \\
644\end{array}$ \\
\hline
\end{tabular}

aNote that this is the measured value before the forced response test. Before the earlier flutter test the value is 375 which is reported in reference 10 .

TABLE 3. - CALCULATED ROTATING BLADE FREQUENCIES

[Frequencies given in $\mathrm{Hz}$.]

\begin{tabular}{|c|c|c|c|c|c|c|c|c|}
\hline \multirow{3}{*}{$\begin{array}{c}\text { Propfan } \\
\text { model }\end{array}$} & \multirow{3}{*}{$\begin{array}{l}\text { Test } \\
\text { point }\end{array}$} & \multirow{3}{*}{$\begin{array}{c}\text { Setting } \\
\text { angle } \\
\mathrm{B}_{3 / 4^{R}} \text {, } \\
\text { deg }\end{array}$} & \multirow{2}{*}{\multicolumn{2}{|c|}{$\begin{array}{l}\text { Rotational } \\
\text { speed }\end{array}$}} & \multicolumn{4}{|c|}{ Mode } \\
\hline & & & & & \multirow{2}{*}{1} & \multirow{2}{*}{2} & \multirow{2}{*}{3} & \multirow{2}{*}{4} \\
\hline & & & rpm & $\mathrm{Hz}$ & & & & \\
\hline$S R-5$ & $\begin{array}{l}8508 \\
8511 \\
8607 \\
8610\end{array}$ & $\begin{array}{l}70.8 \\
70.8 \\
60.8 \\
60.8\end{array}$ & $\begin{array}{l}5500 \\
5500 \\
6000 \\
6000\end{array}$ & $\begin{array}{l}91.67 \\
91.67 \\
100 \\
100\end{array}$ & $\begin{array}{l}140 \\
140 \\
151 \\
151\end{array}$ & $\begin{array}{l}274 \\
274 \\
281 \\
281\end{array}$ & $\begin{array}{l}581 \\
581 \\
586 \\
586\end{array}$ & $\begin{array}{l}628 \\
628 \\
640 \\
640\end{array}$ \\
\hline$S R-3$ & $\begin{array}{l}190 \\
273 \\
277 \\
278\end{array}$ & $\begin{array}{l}48.9 \\
60.8 \\
60.8 \\
60.8\end{array}$ & $\begin{array}{l}8000 \\
8000 \\
7000 \\
8000\end{array}$ & $\begin{array}{l}133.33 \\
133.33 \\
116.67 \\
133.33\end{array}$ & $\begin{array}{l}225 \\
217 \\
208 \\
217\end{array}$ & $\begin{array}{l}453 \\
444 \\
439 \\
444\end{array}$ & $\begin{array}{l}696 \\
693 \\
677 \\
693\end{array}$ & $\begin{array}{l}745 \\
743 \\
733 \\
743\end{array}$ \\
\hline SR $3 C-\times 2$ & 392 & 48 & 5500 & 91.67 & 223 & 408 & 704 & 808 \\
\hline SR $3 C-3$ & 45 & 48 & 5500 & 91.67 & 215 & 435 & 654 & 822 \\
\hline
\end{tabular}

TABLE 4. - SR-5 CALCULATED AND MEASURED STRESSES

[Stresses given in $\left(\mathrm{N} / \mathrm{m}^{2}\right) \times 10^{4}$.]

\begin{tabular}{|c|c|c|c|c|c|c|c|c|c|c|c|c|}
\hline \multirow{3}{*}{$\begin{array}{l}\text { Test } \\
\text { point }\end{array}$} & \multicolumn{3}{|c|}{ Gage 1} & \multicolumn{3}{|c|}{ Gage 3} & \multicolumn{3}{|c|}{ Gage 5} & \multicolumn{3}{|c|}{ Gage 6} \\
\hline & \multirow{2}{*}{$\frac{\text { Measured }}{\text { Normal }}$} & \multicolumn{2}{|c|}{ Calculated } & \multirow{2}{*}{$\frac{\text { Measured }}{\text { Shear }}$} & \multicolumn{2}{|c|}{ Calculated } & \multirow{2}{*}{$\begin{array}{l}\text { Measured } \\
\text { Normal }\end{array}$} & \multicolumn{2}{|c|}{ Calculated } & \multirow{2}{*}{$\begin{array}{c}\text { Measured } \\
\text { Normal }\end{array}$} & \multicolumn{2}{|c|}{ Calculated } \\
\hline & & Normal & Shear & & Normal & Shear & & Normal & Shear & & Normal & Shear \\
\hline $\begin{array}{l}8508 \\
8511 \\
8607 \\
8610\end{array}$ & $\begin{array}{l}2320 \\
5968 \\
5142 \\
1225\end{array}$ & $\begin{array}{r}1886 \\
4701 \\
3023 \\
759\end{array}$ & $\begin{array}{l}295 \\
737 \\
469 \\
118\end{array}$ & $\begin{array}{r}201 \\
301 \\
338 \\
93\end{array}$ & $\begin{array}{r}168 \\
418 \\
259 \\
65\end{array}$ & $\begin{array}{r}43 \\
109 \\
76 \\
19\end{array}$ & $\begin{array}{l}183 \\
687 \\
666 \\
166\end{array}$ & $\begin{array}{l}311 \\
775 \\
479 \\
120\end{array}$ & $\begin{array}{r}248 \\
618 \\
361 \\
90\end{array}$ & $\begin{array}{r}999 \\
2602 \\
4997 \\
1186\end{array}$ & $\begin{array}{l}383 \\
956 \\
610 \\
153\end{array}$ & $\begin{array}{r}243 \\
606 \\
358 \\
90\end{array}$ \\
\hline
\end{tabular}




\section{ORIGINAL PAGE IS \\ OF POOR QUALTY}

TABLE 5. - SR-5 BLADE STRESS VARIATION WITH FREQUENCY MISTUNING

\begin{tabular}{|c|c|c|c|}
\hline Case & . & Case description & $\begin{array}{l}\text { Blade stress, } \mathrm{N} / \mathrm{m}^{2} \\
\text { (Strain gage } 1)\end{array}$ \\
\hline $8508-R$ & \multicolumn{2}{|c|}{$\begin{array}{l}\text { Test point } 8508 \\
\text { Calculated modes and frequencies }\left(f_{1} \text { and } f_{2}\right)\end{array}$} & $1886 \times 10^{4}$ \\
\hline $8508-1$ & Frequencies: & $0.95 f_{1}$ and $0.95 f_{2}$ & 2196 \\
\hline $8508-2$ & Frequencies: & $1.05 f_{1}$ and $1.05 f_{2}$ & 1640 \\
\hline $8508-3$ & Frequencies: & $\begin{array}{l}0.95 f_{1} \text { and } 0.95 f_{2} \text { (odd blades) } \\
1.05 f_{1} \text { and } 1.05 f_{2} \text { (even blades) }\end{array}$ & $\begin{array}{l}a_{2181} \\
b_{1651}\end{array}$ \\
\hline $8508-4$ & Frequencies: & $0.9 f_{1}$ and $0.9 f_{2}$ (biade 1$)$ & 2550 \\
\hline $8508-5$ & Frequencies: & $0.95 f_{1}$ and $0.95 f_{2}$ (b1ade 1$)$ & 2167 \\
\hline $8508-6$ & Frequencies: & $1.05 f_{1}$ and $1.05 f_{2}(b 1$ ade 1$)$ & 1629 \\
\hline $8508-7$ & Frequencies: & $1.1 f_{1}$ and $1.1 f_{2}$ (blade 1 ) & 1436 \\
\hline
\end{tabular}

afor odd blades.

bor even blades.

TABLE 6. - SR-5 BLADE STRESS VARIATION

WITH NUMBER OF BLADES

\begin{tabular}{|c|c|c|}
\hline Case & $\begin{array}{c}\text { Case } \\
\text { description } \\
\text { (number } \\
\text { of blades) }\end{array}$ & $\begin{array}{c}\text { Blade stress, } \mathrm{N} / \mathrm{m}^{2} \\
\text { (Strain gage 1) }\end{array}$ \\
\hline $8508-R$ & 10 & $1886 \times 10^{4}$ \\
$8508-8 B$ & 8 & 2041 \\
$8508-6 B$ & 6 & 2197 \\
$8508-5 B$ & 5 & 2262 \\
$8508-4 B$ & 4 & 2305 \\
$8508-18$ & 1 & 2282 \\
\hline
\end{tabular}

TABLE 7. - SR-3 CALCULATED AND MEASURED BLADE STRESSES [Stresses given in $\left(\mathrm{N} / \mathrm{m}^{2}\right) \times 10^{4}$.]

\begin{tabular}{|c|c|c|c|c|c|c|c|c|c|c|c|c|c|c|c|}
\hline \multirow{3}{*}{$\begin{array}{l}\text { Test } \\
\text { point }\end{array}$} & \multicolumn{3}{|c|}{ Gage 1} & \multicolumn{3}{|c|}{ Gage 2} & \multicolumn{3}{|c|}{ Gage 3} & \multicolumn{3}{|c|}{ Gage 4} & \multicolumn{3}{|c|}{ Gage 5} \\
\hline & \multirow{2}{*}{$\frac{\text { Measured }}{\text { Normal }}$} & \multicolumn{2}{|c|}{ Calculated } & \multirow{2}{*}{$\frac{\text { Measured }}{\text { Normal }}$} & \multicolumn{2}{|c|}{ Calculated } & \multirow{2}{*}{$\frac{\text { Measured }}{\text { Normal }}$} & \multicolumn{2}{|c|}{ Calculated } & \multirow{2}{*}{$\begin{array}{c}\text { Measured } \\
\text { Shear }\end{array}$} & \multicolumn{2}{|c|}{ Calculated } & \multirow{2}{*}{$\begin{array}{c}\text { Measured } \\
\text { Normal }\end{array}$} & \multicolumn{2}{|c|}{ Calculated } \\
\hline & & Normal & Shear & & Normal & Shear & & Normal & Shear & & Normal & Shear & & Normal & Shear \\
\hline $\begin{array}{l}190 \\
273 \\
277 \\
278\end{array}$ & $\begin{array}{l}1590 \\
1291 \\
2426 \\
2575\end{array}$ & $\begin{array}{l}1273 \\
1553 \\
2911 \\
3075\end{array}$ & $\begin{array}{l}323 \\
354 \\
647 \\
700\end{array}$ & $\begin{array}{r}732 \\
594 \\
970 \\
1184\end{array}$ & $\begin{array}{r}623 \\
699 \\
1264 \\
1382\end{array}$ & $\begin{array}{r}55 \\
66 \\
103 \\
130\end{array}$ & $\begin{array}{r}1177 \\
956 \\
1926 \\
1905\end{array}$ & $\begin{array}{r}788 \\
914 \\
1804 \\
1809\end{array}$ & $\begin{array}{l}192 \\
205 \\
472 \\
407\end{array}$ & $\begin{array}{l}167 \\
136 \\
303 \\
270\end{array}$ & $\begin{array}{r}616 \\
680 \\
1339 \\
1346\end{array}$ & $\begin{array}{r}69 \\
60 \\
154 \\
119\end{array}$ & $\begin{array}{r}644 \\
523 \\
1120 \\
1042\end{array}$ & $\begin{array}{l}351 \\
372 \\
699 \\
736\end{array}$ & $\begin{array}{l}38 \\
31 \\
96 \\
61\end{array}$ \\
\hline
\end{tabular}


TABI.E 8. - SR3C-X2, SR3C-3, AND SR3C-X2/SR3C-3 CALCULATED AND MEASURED BLADE STRAINS

\begin{tabular}{|c|c|c|c|c|c|c|c|}
\hline \multirow{2}{*}{$\begin{array}{l}\text { Test } \\
\text { point }\end{array}$} & \multirow{2}{*}{$\begin{array}{l}\text { Propfan } \\
\text { model }\end{array}$} & \multicolumn{4}{|c|}{ Gage 1} & \multicolumn{2}{|c|}{ Gage 2} \\
\hline & & Measured & Calculated & $\begin{array}{c}\text { Calculated } \\
\text { with } \\
\text { measured } \\
\text { frequency }\end{array}$ & $\begin{array}{c}\text { Calculated } \\
\text { with } \\
\text { arbitrary } \\
\text { mistuning }\end{array}$ & Measured & Calculated \\
\hline $\begin{array}{r}392 \\
45 \\
768 \\
768\end{array}$ & $\begin{array}{l}\text { (SR3C-X2) } \\
\text { ( SR3C-3) } \\
\text { ( SR3C-X2) } \\
\text { ( SR3C-3) }\end{array}$ & $\begin{array}{l}257 \times 10^{-6} \\
195 \\
143 \\
177\end{array}$ & $\begin{array}{l}a_{2} 201 \times 10^{-6} \\
d_{287} \\
f_{199} \\
f_{152}\end{array}$ & $\begin{array}{l}b_{219 \times 10^{-6}} \\
e_{252} \\
g_{164} \\
g_{153}\end{array}$ & 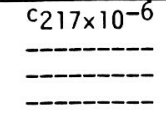 & $\begin{array}{l}358 \times 10^{-6} \\
165 \\
161 \\
135\end{array}$ & $\begin{array}{l}d_{46}^{80 \times 10^{-6}} \\
f_{47} \\
f_{50}\end{array}$ \\
\hline
\end{tabular}

$a_{f_{1}}=223 \mathrm{~Hz} ; f_{2}$ 口 $408 \mathrm{~Hz}$

$b_{f_{1}}=223 \mathrm{~Hz} ; f_{2}=371 \mathrm{~Hz}$.

$c_{f_{1}}=223,230,219,219,223,223,225,230 \mathrm{~Hz}$.

$f_{2}=371,386,367,367,367,382,382,367 \mathrm{~Hz}$.

$d_{f_{1}}=215 \mathrm{~Hz} ; f_{2}=435 \mathrm{~Hz}$.

$e_{f_{1}}=230 \mathrm{~Hz} ; f_{2}=435 \mathrm{~Hz}$.

$f_{f_{1}}=223 \mathrm{~Hz} ; f_{2}=407 \mathrm{~Hz}(-x 2$ blade $) ; f_{1}$ व $215 \mathrm{~Hz} ; f_{2}=435 \mathrm{~Hz}(-3$ blade $)$.

$g_{f_{1}}=223 \mathrm{~Hz} ; f_{2}=371 \mathrm{~Hz}(-x 2$ blade $) ; f_{1}$ व $230 \mathrm{~Hz} ; f_{2}=435 \mathrm{~Hz}(-3$ blade $)$.

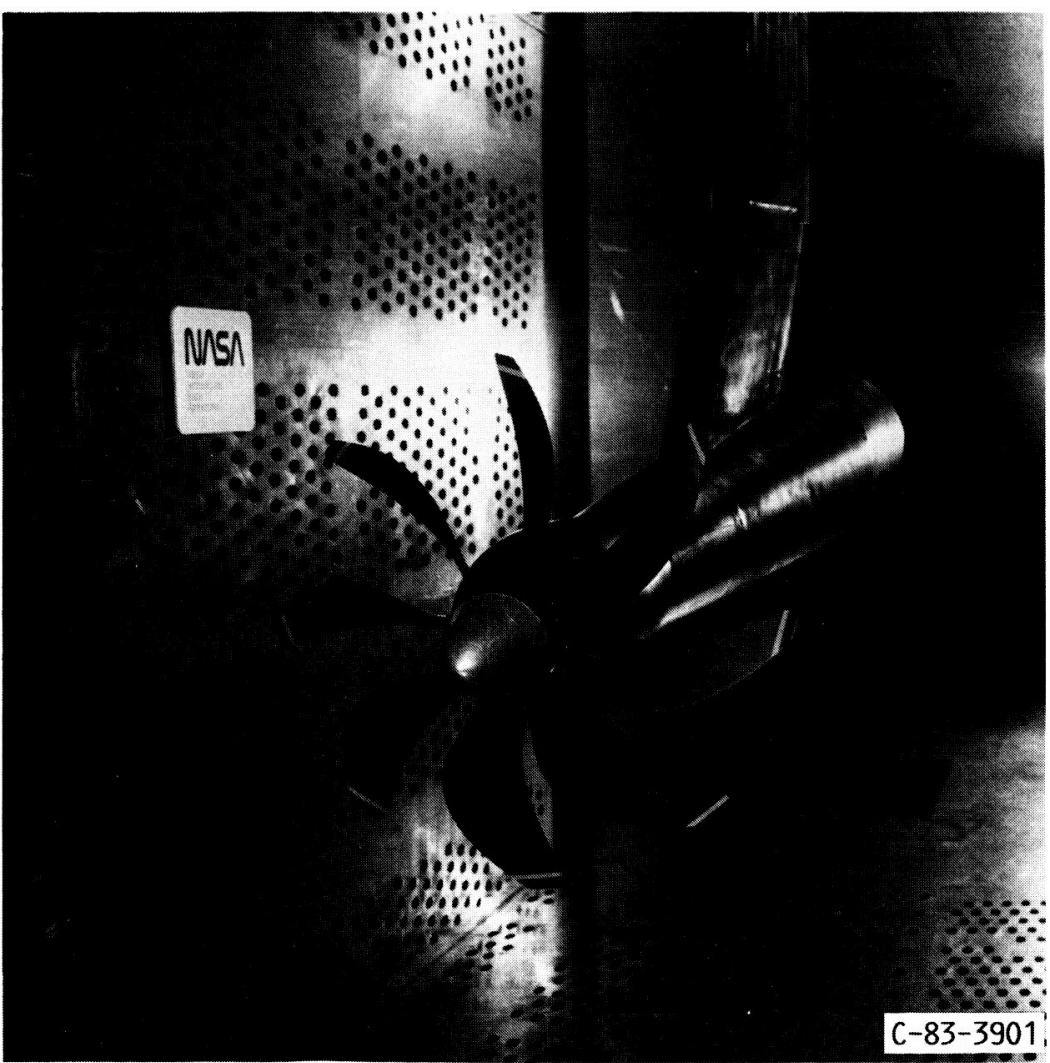

FIGURE 1. - SR3C-X2 PROPFAN MODEL WIND TUNNEL INSTALLATION. 


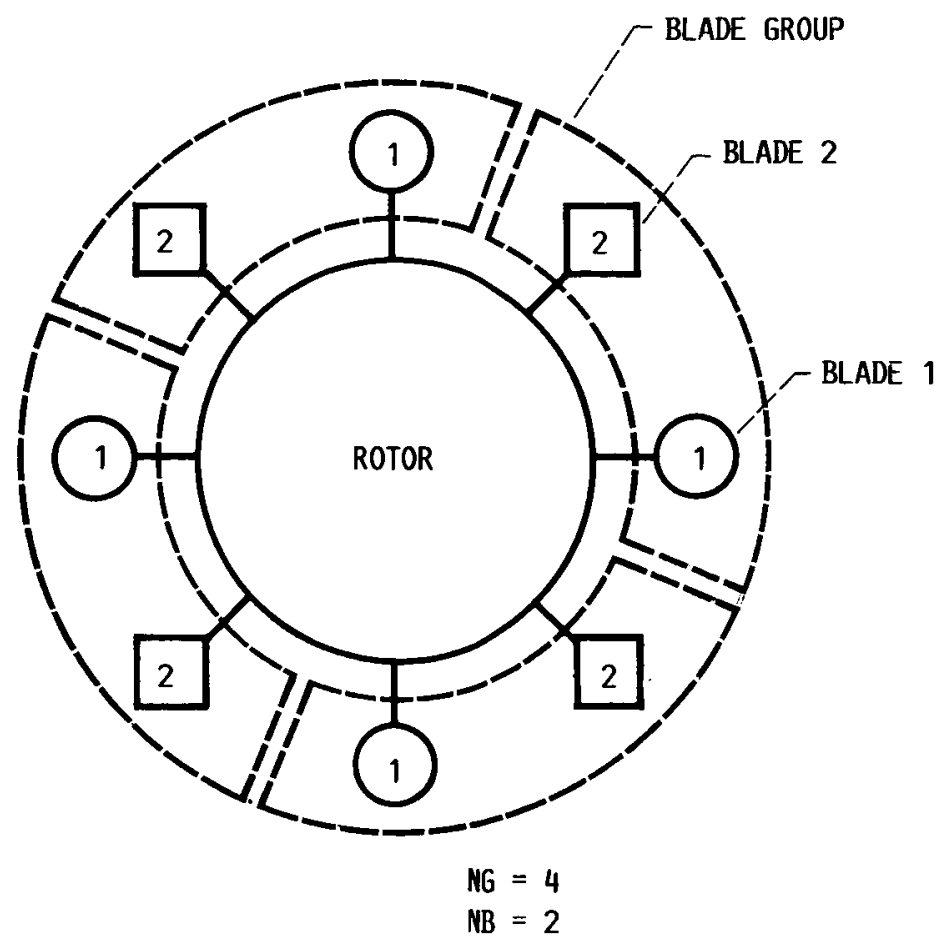

FIGURE 2. - BLADE GROUP SCHEMATIC FOR AN EIGHT-BLADED ROTOR.

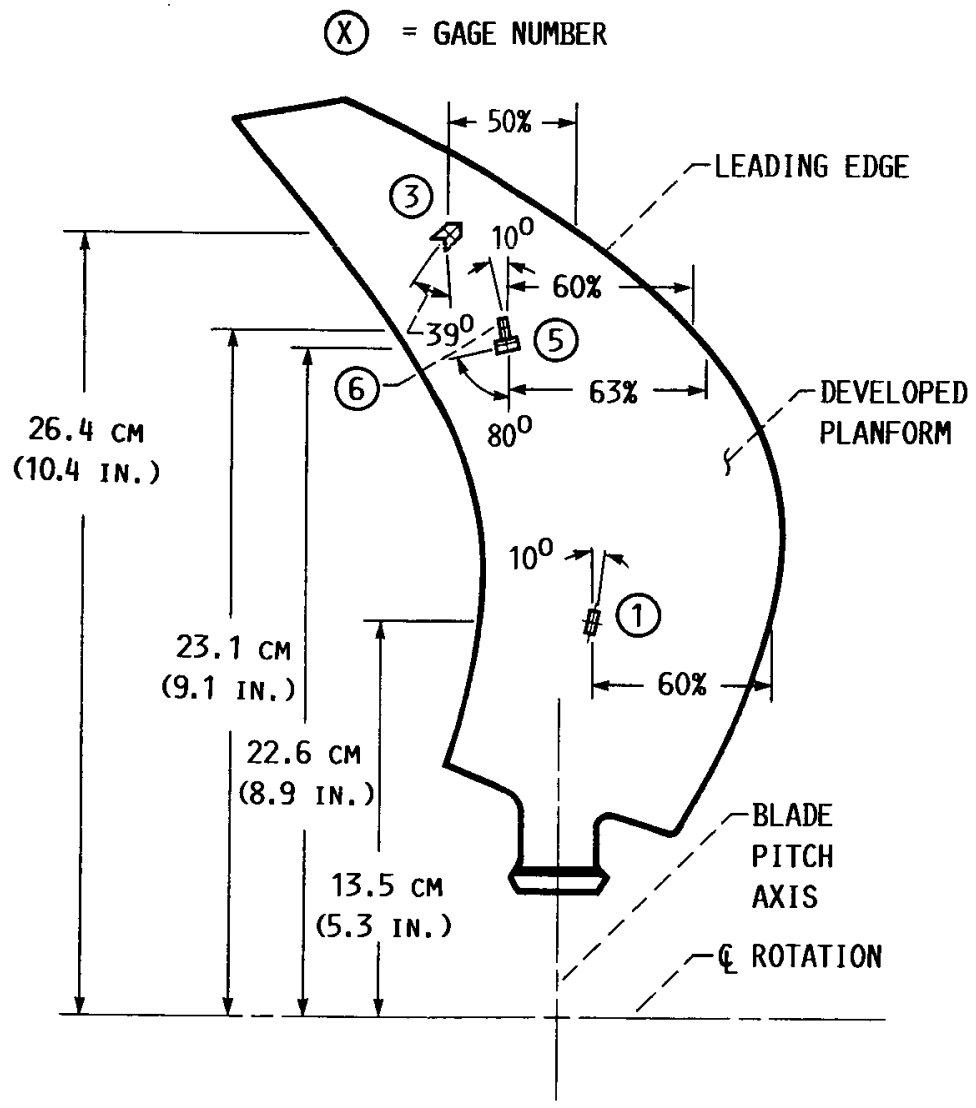

FIGURE 3. - SR-5 STRAIN GAGE LOCATIONS (SUCTION SIDE). 


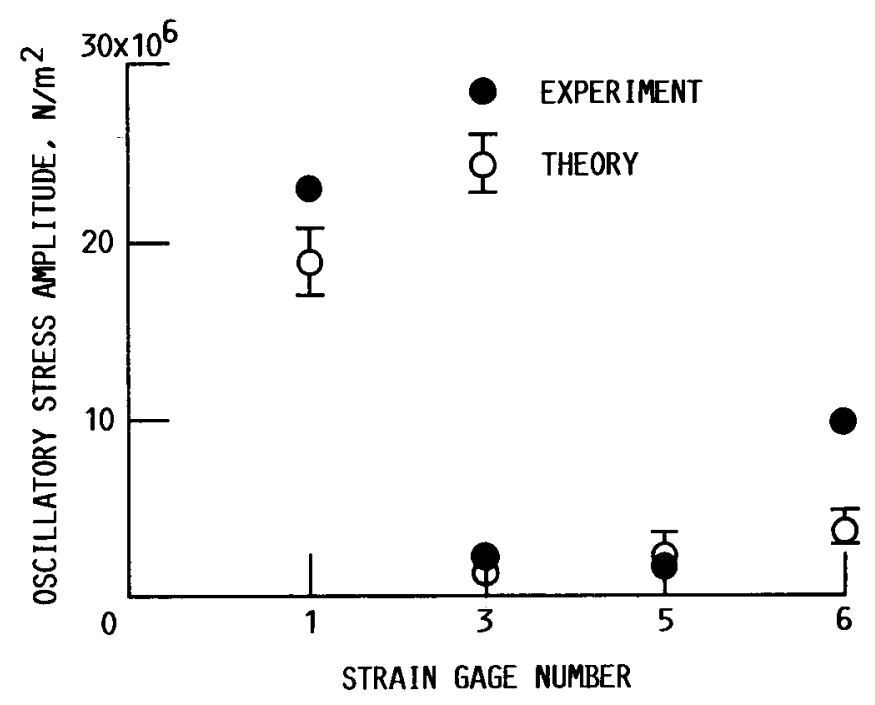

FIGURE 4. - COMPARISON OF CALCULATED AND MEASURED BLADE STRESSES: SR-5 MODEL TEST POINT NUMBER 8508.

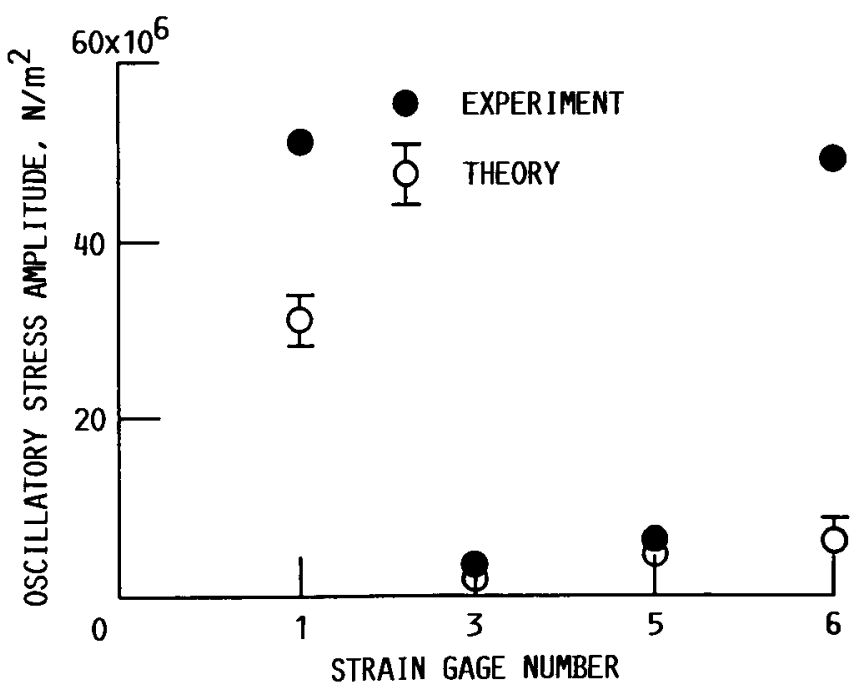

FIGURE 6. - COMPARISON OF CALCULATED AND MEASURED BLADE STRESSES: SR-5 MODEL TEST POINT NUMBER 8607.

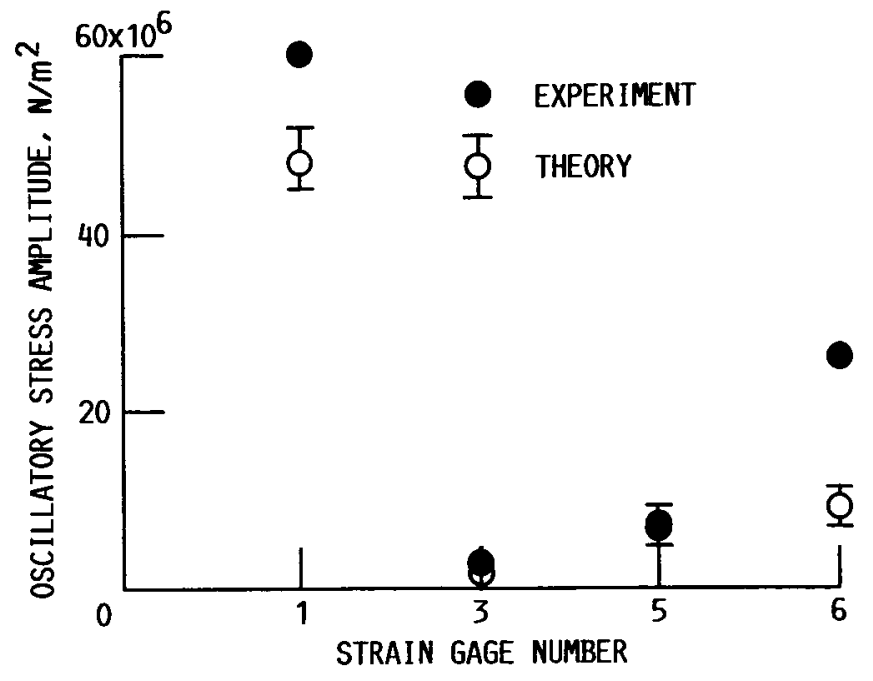

FIGURE 5. - COMPARISON OF CALCULATED AND MEASURED BLADE STRESSES: SR-5 MODEL TEST POINT NUMBER 8511.

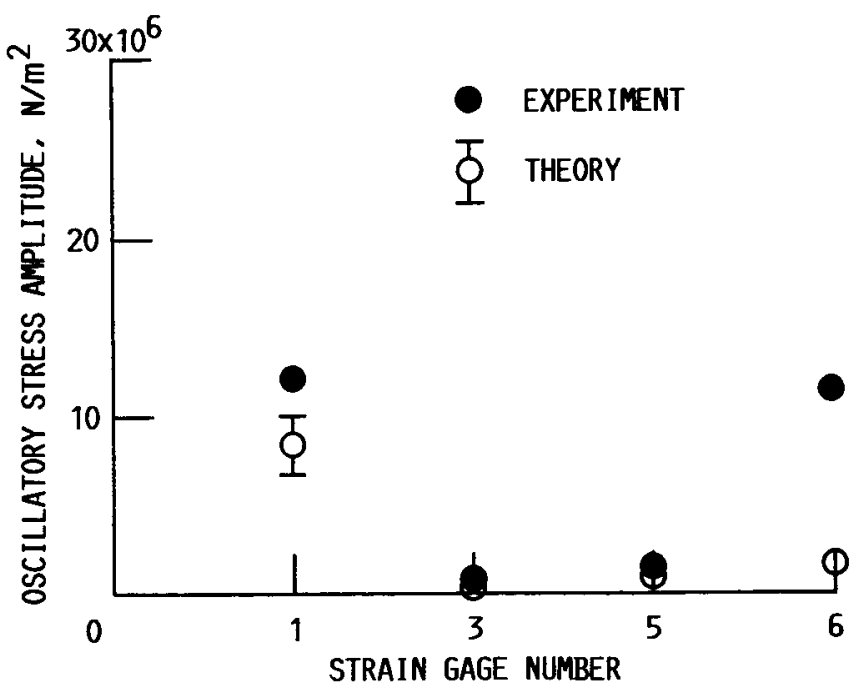

FIGURE 7. - COMPARISON OF CALCULATED AND MEASURED BLADE STRESSES: SR-5 MODEL TEST POINT NUMBER 8610. 


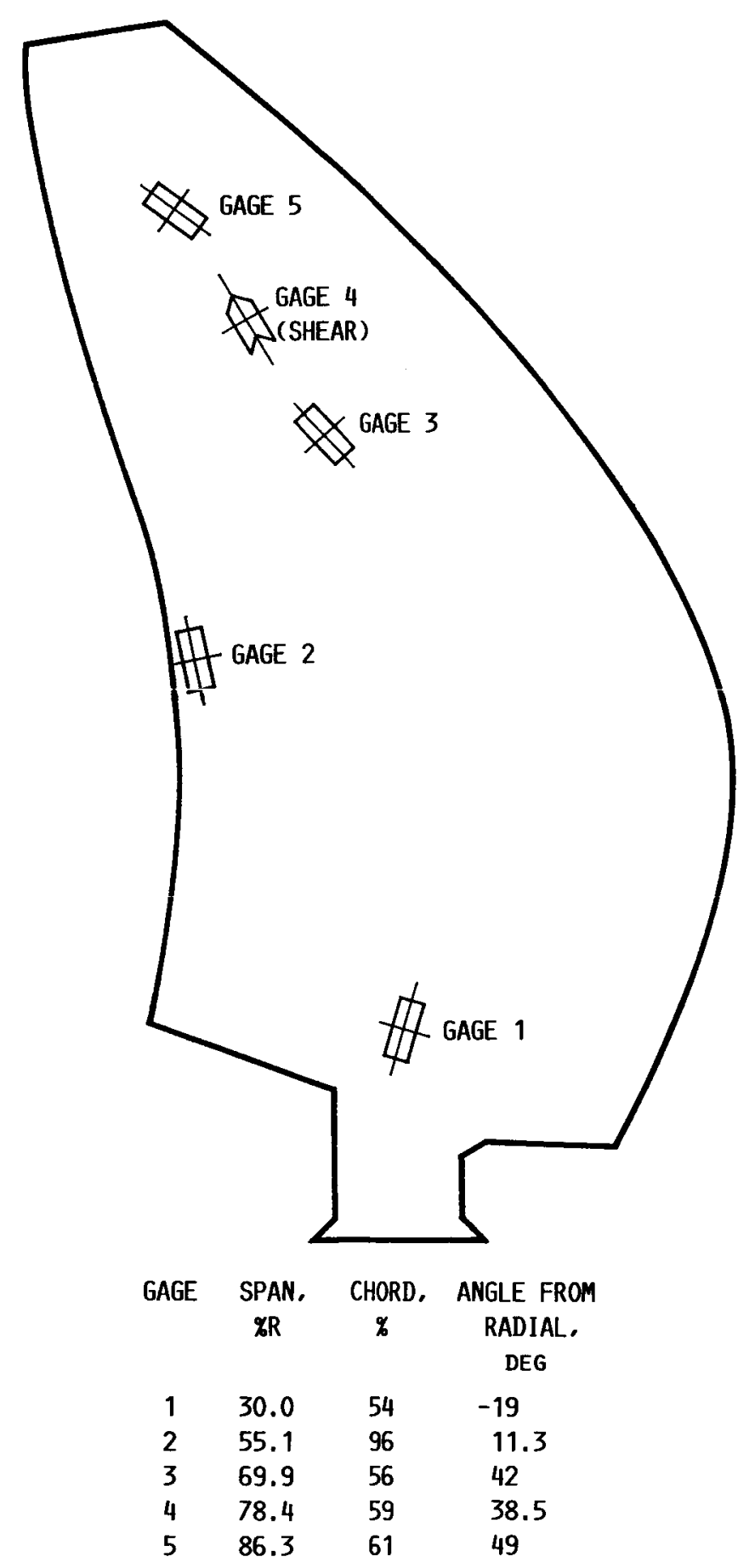

FIGURE 8. - SR-3 STRAIN GAGE LOCATIONS (SUCTION SIDE). 


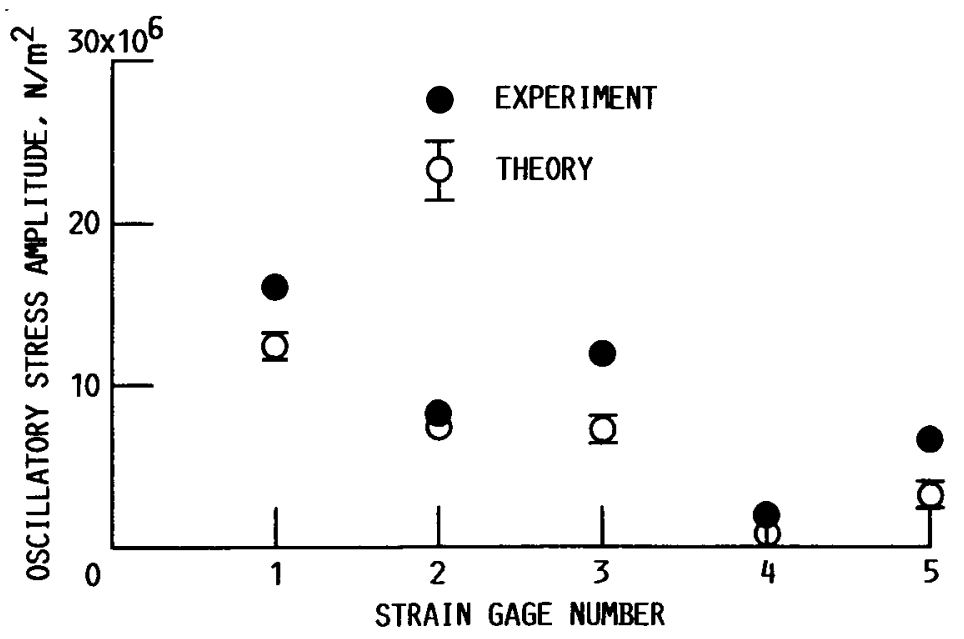

FIGURE 9. - COMPARISON OF CALCULATED AND MEASURED BLADE STRESSES: SR-3 MODEL TEST POINT NUMBER 190.

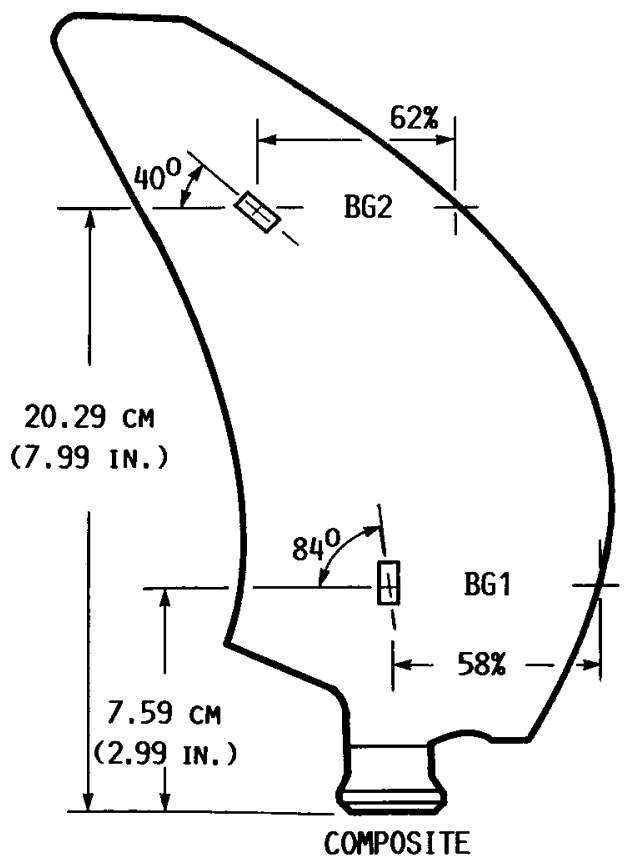

FIGURE 10. - SR3C-X2 AND SR3C-3 STRAIN GAGE LOCATIONS (SUCTION SIDE). 


\begin{tabular}{|c|c|c|c|}
\hline \multicolumn{4}{|l|}{$\mathbf{W}_{\substack{\text { National Aeronauvicis ano } \\
\text { space Administration }}}$} \\
\hline $\begin{array}{ll}\text { 1. Report No. } & \text { NASA TM-100964 } \\
\text { AIAA- } 88-3154\end{array}$ & 2. Government Accession No. & \multicolumn{2}{|c|}{ 3. Recipient's Catalog No. } \\
\hline \multicolumn{2}{|c|}{$\begin{array}{l}\text { 4. Title and Subtitle } \\
\text { Aeroelastic Response of Metallic and Composite } \\
\text { Propfan Models in Yawed Flow }\end{array}$} & \multicolumn{2}{|l|}{ 5. Report Date } \\
\hline \multirow{2}{*}{\multicolumn{2}{|c|}{$\begin{array}{l}\text { 7. Author(s) } \\
\text { Krishna Rao V. Kaza, Marc H. Willi iams } \\
\text { Oral Mehmed, G.V. Narayanan }\end{array}$}} & \multicolumn{2}{|c|}{$\begin{array}{l}\text { 8. Performing Organization Report No. } \\
\text { E-4229 }\end{array}$} \\
\hline & & \multicolumn{2}{|c|}{$\begin{array}{l}\text { 10. Work Unit No. } \\
505-63-18\end{array}$} \\
\hline \multirow{2}{*}{\multicolumn{2}{|c|}{$\begin{array}{l}\text { National Aeronautics and Space Administration } \\
\text { Lewis Research Center } \\
\text { Cleveland, Ohio } 44135-3191\end{array}$}} & \multicolumn{2}{|c|}{ 11. Contract or Grant No. } \\
\hline & & \multirow{2}{*}{\multicolumn{2}{|c|}{$\begin{array}{l}\text { 13. Type of Report and Period Covered } \\
\text { Technical Memorandum }\end{array}$}} \\
\hline \multicolumn{2}{|l|}{ 12. Sponsoring Agency Name and Address } & & \\
\hline \multicolumn{2}{|c|}{$\begin{array}{l}\text { National Aeronautics and Space Administration } \\
\text { Washington, D.C. 20546-0001 }\end{array}$} & \multicolumn{2}{|c|}{ 14. Sponsoring Agency Code } \\
\hline \multicolumn{4}{|c|}{ 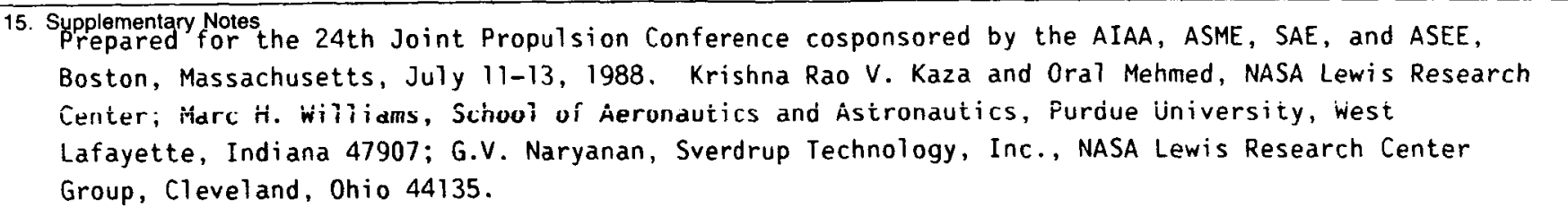 } \\
\hline \multirow{2}{*}{\multicolumn{4}{|c|}{$\begin{array}{l}\text { 16. Abstract } \\
\text { An analytical investigation of aeroelastic response of metallic and composite } \\
\text { propfan models in yawed flow has been performed. The analytical model is based } \\
\text { on the normal modes of a rotating blade and the three-dimensional unsteady lift- } \\
\text { ing surface aerodynamic theory including blade mistuning. The calculated blade } \\
\text { stresses or strains are compared with published wind tunnel data on two metallic } \\
\text { and three composite propfan wind tunnel models. The comparison shows a good } \\
\text { agreement between theory and experiment. Additional parametric results indicate } \\
\text { that blade response is very sensitive to the blade stiffness and also to blade } \\
\text { frequency and mode shape mistuning. From these findings, it is concluded that } \\
\text { both frequency and mode shape mistuning should be included in aeroelastic } \\
\text { response analysis. Furthermore, both calculated and measured strains show that } \\
\text { combined blade frequency and mode shape mistuning has beneficial effects on } \\
\text { response due to yawed flow. }\end{array}$}} \\
\hline & & & \\
\hline \multicolumn{2}{|l|}{ 17. Key Words (Suggested by Author(s)) } & \multicolumn{2}{|c|}{ 18. Distribution Statement } \\
\hline $\begin{array}{l}\text { Aeroelasticity } \\
\text { Propfan } \\
\text { Aeroelastic response }\end{array}$ & & \multicolumn{2}{|c|}{$\begin{array}{l}\text { Unclassified - Unlimited } \\
\text { Subject Category } 07\end{array}$} \\
\hline $\begin{array}{l}\text { 19. Security Classif. (of this report) } \\
\text { Unclas s if ied }\end{array}$ & $\begin{array}{l}\text { 20. Security Classif. (of this page) } \\
\qquad \text { Unc las s if ied }\end{array}$ & $\begin{array}{r}\text { 21. No of pages } \\
26\end{array}$ & $\begin{array}{r}\text { 22. Price }{ }^{*} \\
\mathrm{A03}\end{array}$ \\
\hline
\end{tabular}

